\title{
Economic Crisis and Share Price Unpredictability: Reasons and Implications
}

Posted by June Rhee, Co-editor, HLS Forum on Corporate Governance and Financial Regulation, on Thursday, July 10, 2014

Tags: Erica John Fund v. Halliburton, Financial crisis, Fraud-on-the-Market, Information environment, Market reaction, Securities litigation, Stock mispricing More from: Edward Fox, Merritt Fox, Ronald Gilson

Editor's Note: The following post comes to us from Edward G. Fox of University of Michigan at Ann Arbor, Department of Economics, Merritt B. Fox, the Michael E. Patterson Professor of Law at Columbia Law School, and Ronald J. Gilson, Charles J. Meyers Professor of Law and Business at Stanford Law School.

During the recent financial crisis, there was a dramatic spike in "idiosyncratic volatility" - the volatility of individual firm share prices after adjustment for movements in the market as a whole. The average firm's increase was a remarkable five-fold as measured by variance. This dramatic spike is not peculiar to the most recent crisis. Rather, it has occurred with each major downturn in the economy since the 1920s, as our paper shows for the first time. These spikes present a puzzle in terms of existing economic theory. They also have important implications for several areas of corporate and securities law where the capacity of securities prices to reflect available information is particularly important. Examples include the presumption of reliance, loss causation and materiality in fraud-onthe-market suits, materiality in insider trading cases, and the corporate law regulation of defenses undertaken by targets of hostile takeover attempts. The continuing centrality of these issues is underscored by this week's decision in Halliburton Co $v$. Erica P. John Fund, where the Supreme Court ruled that a defendant can defeat a fraud-on-the-market case class certification by showing that the alleged misstatement had no impact on price.

Our empirical review, extending back to 1926, shows that every major economic downturn in this 85-year period has been accompanied by a substantial spike in idiosyncratic volatility. For the most recent crisis, we look as well at what happened in different sectors in the economy, broken down by two-digit SIC code. The increase in idiosyncratic risk was particularly spectacular in the eight such sectors associated with finance, but there was a substantial increase in every one of the 52 non-financial sectors as well. We also examine the impact of the increase in firm debt/equity ratios resulting from the drop in their share prices during the recent crisis. Greater effective leverage resulting from a share price drop will increase a firm's idiosyncratic volatility. This greater leverage, however, is found to explain only a small portion of the observed spike in idiosyncratic volatility.

These results thus pose a puzzle. In an efficient market, movement in a firm's share price is caused by a bit of news that changes investors' expectations concerning the firm's future cash flows. Some bits of news affect expectations about the future cash flows of most or all firms in the market because they concern expectations concerning factors affecting the overall state of economy. These bits are the source of the "systematic" portion of the total volatility in a firm's share price. The remaining volatility in the firm's share price is due to news that affects just expectations about its particular cash flows. This is the "idiosyncratic" portion that spikes sharply with each major economic downturn. An economic crisis concerns problems in the economy as a whole. So the puzzle is what in crisis periods would make information that is completely independent of what is happening in the economy as a whole suddenly so much more consequential?

One explanation is that, compared to ordinary times, firm-specific information contained in current news may become more important in predicting its future cash flows relative to the role of the already existing stock of firm specific knowledge. A second explanation is that the quality of management becomes more important in crisis times. Consequently, the ordinary flow of new information about this subject can cause bigger movements in price because each bit tells the market about something - the quality of management-that the market now regards as 
more important. A third is that crisis may create uncertainty as to what factors are even important to valuation. Thus a broader range of firm-specific information may have valuation implications. A fourth is that crisis reveals firms with fraudulent or inept managers who had masked their problems in the preceding good times, with resulting large movements in their share prices. A fifth explanation is noise trading: the impact on stock prices of unsophisticated or irrational traders. We conclude that the first three explanations are more convincing than the latter two.

Our empirical results and their possible explanations have important implications for a number of legal issues that depend analytically on valuation methodology. Litigation with respect to such matters has, over the last few decades, increasingly involved the empirical analysis, through event studies, of the idiosyncratic portion of share returns of the companies involved. This increase has occurred without an appreciation of the spike in idiosyncratic volatility that accompanies each patch of bad economic times.

One such issue relates to the use of event studies for determining loss causation and materiality in fraud-on-themarket class actions by investors claiming that they suffered losses because corporate misstatements in violation of Rule $10 \mathrm{~b}-5$ artificially inflated the prices that they paid. If the usual standard of statistical significance is maintained in crisis times, a test that in normal times catches most misstatements with corrective disclosures having, for example, a $5 \%$ actual impact on price, would catch relatively few. But, if in response to this problem, the standard is lowered in crisis times, liability will then also be imposed more frequently where the misstatement in fact had no significant impact on price. In the end, our analysis shows that lowering the standard in times of crisis is, on balance, no more likely to improve than to harm social welfare. Thus private damages litigation is simply less effective at deterring corporate misstatements in crisis times. This suggests that crisis times require greater SEC enforcement efforts.

An analysis of materiality determinations in private insider trading actions shows that they are similarly less effective deterrents in crisis times, suggesting the need for greater crisis-times SEC enforcement in this area as well. This conclusion takes on particular significance because the information-based explanations for the spikes in idiosyncratic volatility that we find most persuasive suggest that in such times insiders have substantially more opportunities to profit from trading on the non-public information that they possess.

Finally, we consider takeover defenses by target firms against hostile takeover bids. We show that crisis-induced increases in idiosyncratic risk provide a more plausible basis than in normal times for a claim of "substantive coercion"-a doctrine under Delaware corporate law that permits target boards to authorize takeover defenses where there is a substantial chance that shareholders might mistakenly tender into an offer not in their best interests-but that the claim will still be difficult to establish.

The full empirical study is available here. 